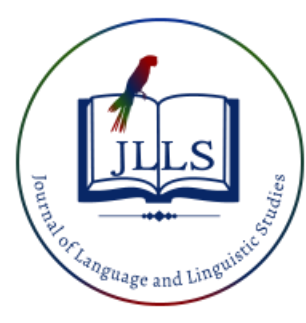

Available online at www.jlls.org

JOURNAL OF LANGUAGE

AND LINGUISTIC STUDIES

ISSN: $1305-578 \mathrm{X}$

Journal of Language and Linguistic Studies, 17(1), 327-345; 2021

\title{
A critical perspective in terms of SOLO taxonomy for reading outcomes in mother-tongue teaching curriculums (1981, 2006 and 2019) in Turkey
}

\author{
Sevil Hasirci Aksoy a 1 \\ ${ }^{a}$ Gaziantep University, Gaziantep, Turkey
}

\section{APA Citation:}

Hasirci Aksoy, S., (2021). A critical perspective in terms of SOLO taxonomy for reading outcomes in mother-tongue teaching curriculums (1981, 2006 and 2019) in Turkey. Journal of Language and Linguistic Studies, 17(1), 327-345. Doi: 10.52462/jlls.20

Submission Date: 08/01/2021

Acceptance Date: 12/03/2021

\begin{abstract}
Reading skill is important to improve children's higher-order thinking skills. But PISA reading results show that children in Turkey are not sufficient for this skill. That's why this study aimed to investigate the cognitive levels of reading outcomes included in the Turkish course curriculum in terms of The Structure of Observed Learning Outcomes (SOLO) taxonomy related to PISA reading competencies. The learning outcomes that constitute the data source of the research were taken from the secondary school Turkish language course curriculum published by the Teaching and Education Board of the Ministry of National Education in 1981, 2006, and 2019. After completing a document analysis on the reading outcomes, the data obtained were evaluated with descriptive content analysis. The results showed that relational level stands out in terms of percentage of reading outcomes, and this level is mostly in the 2019 curriculum. While the uni-structural level has been decreasing over the years, relational and extended abstract levels have increased. Even if an extended abstract cognitive level has increased over the years, it is still one of the least levels in the curriculums. When subskills of reading are compared, the most widely used is the reading comprehension theme. As a result of the study, it was concluded that there is a need to be handled in a coordinated manner in the reading outcomes of the curriculums in terms of cognitive skills and reading subskills.
\end{abstract}

Keywords: Turkish language course, reading skill, curriculums, SOLO taxonomy, reading outcomes

\section{Introduction}

The individual is expected to acquire impressions of life, people, and nature by making inferences, interpretation, association, questioning nowadays. When looked at the Turkish lesson curriculum, the goal "to acquire linguistic and mental skills, develop themselves individually and socially by using these skills, establish effective communication, acquire the habit of reading and writing" stand out (MoNE [MEB], 2019, p.8). As it is seen, it is aimed to improve the linguistic and cognitive skills of the students in the Turkish language curriculum. For the improvement of the cognitive skills of

\footnotetext{
1 Corresponding author.

E-mail address: sevilhasirci@gmail.com
} 
students, students need to make a practice insightful problem solving and productive thinking (Senemoglu, 2004), expand their capacity to create the results they truly desire (Senge, 1994).

The development of linguistic skills is essential to the development of individuals' thinking skills. Individuals who achieve this level are able to receive the input through the skills of reading and listening and produce output through the skills of writing and speaking, thus reflecting the thinking process. Students, for the task of learning, should be able to "understand a new idea (which requires it to be located in a semantic syntactical network of concepts), judge its truth value (which requires relating the idea to appropriate standards of evidence), and evaluate its consistency with other ideas (which may require alterations in the overall conceptual organization)." (Strike \& Posner, 1985, p.212). The process of comprehension, evaluation, and judgment requires individuals to use their higher-order thinking skills. Because thinking skills involve "asserting arguments, making determinations, providing evidence, making conclusions, making definitions, bringing clarity,..." (Cin Seker, 2020, p.994). Therefore, it is crucial to develop the students' reception, perception, integration, classification, questioning, and criticism abilities in the process of them acquiring reading skills. This can also be seen in PISA results:

Table 1. PISA reading test results for Turkey

\begin{tabular}{|c|c|c|c|c|c|c|c|c|}
\hline & & $\begin{array}{l}\text { Below } \\
\text { Level } 1\end{array}$ & Level 1 & Level 2 & Level 3 & Level 4 & Level 5 & Level 6 \\
\hline & $\begin{array}{l}\text { Below } \\
\text { Level 1b }\end{array}$ & $1 \mathrm{~b}$ & $1 \mathrm{a}$ & & & & & \\
\hline 2003 & - & 12,5 & 24,5 & 30,9 & 20,8 & 7,7 & 3,8 & - \\
\hline 2006 & - & 10,8 & 21,4 & 31,0 & 24,5 & 10,3 & 2,1 & - \\
\hline 2009 & 0,8 & 5,6 & 18,1 & 32,2 & 29,1 & 12,4 & 1,8 & 0 \\
\hline 2012 & 0,6 & 4,5 & 16,6 & 30,8 & 28,7 & 14,5 & 4,1 & 0,3 \\
\hline 2015 & 13,2 & & 26,8 & 32,6 & 21,1 & 5,7 & 0,6 & 0 \\
\hline 2018 & 7,0 & & 19,1 & 30,2 & 26,9 & 13,5 & 3,1 & 0,2 \\
\hline
\end{tabular}

According to the PISA results (Table 1), no significant progress has been achieved since 2003 in terms of students' higher-order thinking skills (level 5). There was a particular decrease in 2015, and the level was only $0.2 \%$ in 2018 . In terms of higher-order thinking skills, the number of students responding at level 5 decreased in the 2009 exam, which was the first reflection of the 2006 curriculum (MoNE, 2006); however, an increase was achieved in 2012. However, no significant difference existed in terms of proportional context between the values in the 2012 exam and the 2003 exam, which reflects the 1981 curriculum (MoNE, 1981). Moreover, there was a decrease in 2018. For this reason, it is necessary to determine which aspects of the students' thinking process are emphasized by the outcomes aimed at improving their reading skills. Thus, for each learning outcome, the process of teaching students to think will be determined systematically. This has led to the question of the extent to which higher cognitive skills are included in reading outcomes in the Turkish curriculum.

\subsection{Literature review}

Many factors, such as teachers, curricula, teaching approaches, methods, and techniques, play an important role in improving students' thinking skills. According to Piaget, Vygotsky, and Bruner, the instruction that should be given to children is determined by how they think and how their cognitive 
development occurs. For this reason, the curriculum and methods to be administered in schools should be appropriate for children's cognitive structures and enable them to enrich their existing cognitive structures through assimilation and accommodation (Senemoglu, 2012). The Structure of Observed Learning Outcomes (SOLO) taxonomy is internationally known and used to determine the cognitive levels of learning outcomes in a curriculum (Ar1, 2013). This taxonomy stands out among the others because it functions parallel to Piaget's cognitive development stages, is similar to the PISA reading competency levels ( $\mathrm{Li}, \mathrm{Gao} \& \mathrm{Cao}, 2011)$, and yields higher rates of generalizability and reliability than the revised Bloom taxonomy does in determining cognitive levels (Hattie \& Purdie, 1994; Ilhan \& Gezer, 2017; Meagher-Lundberg \& Brown, 2001).

Table 2. Cognitive development and SOLO levels

\begin{tabular}{lll}
\hline Cognitive Development Stages & Logical Operation2 & SOLO Levels \\
\hline Pre-operational (4-6 years) & & Pre-Structural \\
Early Concrete (7-9 years) & Giving names/Classification & Uni-Structural \\
Middle Concrete (10-12 years) & Seriation & Multi-Structural \\
Late Concrete (13-15 years) & Transitivity & Relational \\
Formal Operational (16 + years) & Proportionality- Early Concrete & Extended Abstract \\
& Correlation- Late Concrete & \\
\hline Note. Adapted from Biggs \& Collis, 1982, p.24-25; Decano, 2017; Fusco, 1983, p.55 and Li et al, 2011. &
\end{tabular}

As can be seen in Table 2, it can be inferred that students take the PISA exams after they have completed the late concrete stage and switched to the formal operations stage. This means that students taking this exam can perform cognitive operations such as giving names and seriation as well as identifying the relationships among components in a context - in other words, the relationships between elements that make up the whole (for example, thoughts in a paragraph, messages and supplementary messages in a text, words forming a text, word groups, and phrases), the variables that validate/do not validate an assumption, and even the proportional variations in independent texts.

Using Piaget's development model, Applebee (1978, p. 20) created a systematic model of the main developmental stages in formulating responses. This model was presented in the following manner:

Table 3. Characteristic response

\begin{tabular}{lll}
\hline $\begin{array}{l}\text { Mode of Thinking } \\
\text { Pre-operational }\end{array}$ & $\begin{array}{l}\text { Objective } \\
\text { Narration, in whole or part }\end{array}$ & $\begin{array}{l}\text { Subjective } \\
\text { Syncretism, lacking integration }\end{array}$ \\
Late concrete & $\begin{array}{l}\text { Summarization and categorization } \\
\text { Categorization, attributed to the } \\
\text { work }\end{array}$ \\
Formal Operational & $\begin{array}{l}\text { Analysis of the structure of the work or } \\
\text { the motives of the characters; involvement in the work } \\
\text { understanding through analogy } \\
\text { Generalization about the work; The understanding gained or not } \\
\text { consideration of its theme or point of gained through the work; its effect }\end{array}$
\end{tabular}

${ }^{2}$ Giving names/Classification- Ability to name and identify sets of objects according to appearance, size, or other characteristics, including the idea that one set of objects can include another.

Seriation: Ability to sort objects in an order according to size or other characteristics.

Transitivity: Ability to recognize relationships among various things in a serial order

Proportionality: Ability to determine the relative magnitude of the increase and decrease of ratios.

Correlation: Ability to recognize a comparison between the number of confirming and disconfirming cases of a hypothesized relationship to

the total number of cases (Decano, 2017, p.61). 
Based on Applebee (1978) definitions, 15-year-old individuals analyze the structure of the text and make sense of it by establishing analogy. In other words, they are expected to determine the relational aspect of each feature that makes up the text. From this point of view, it is important to determine how parallel the reading outcomes are in each curriculum with the students' cognitive-development levels.

The SOLO taxonomy, which is based on research on students' learning, describes a structure in which each structure is the basis for the next learning stage (Biggs \& Tang, 2007, p.79-80). This basis provides teachers with a systematic and hierarchical way to help students develop their thinking skills while responding to each question and helps teachers and students with understanding and evaluating learning experiences and outcomes in terms of cognitive complexity (Brabrand \& Dahl, 2009; Hattie \& Brown, 2004).

The SOLO taxonomy focuses on bidirectional knowing: declarative knowledge and procedural knowledge. Declarative knowledge requires explaining something, integrating subjects, and relating them to the teaching context rather than only defining and listing. Procedural knowledge, on the other hand, is related to the abstract level of comprehension and is based on the originality of students through which they can establish a context with their own processing theory. Therefore, SOLO is a taxonomy structured on designing a learning experience for declarative knowledge (knowing) and procedural knowledge (Biggs and Tang 2007, p.81-84). For instance, it is more possible to design a learning experience through an indicator verb for declarative knowledge at the relational level for comparison and contrast. This enables teachers or researchers to assess the learning outcomes of students or to evaluate students' responses based on the criterion for attainments stated at unistructural, multi-structural, relational and extended abstract levels (Hook, 2012, p.123). This also allows them to functionally evaluate learning design and outcomes through indicator verbs at each cognitive level.

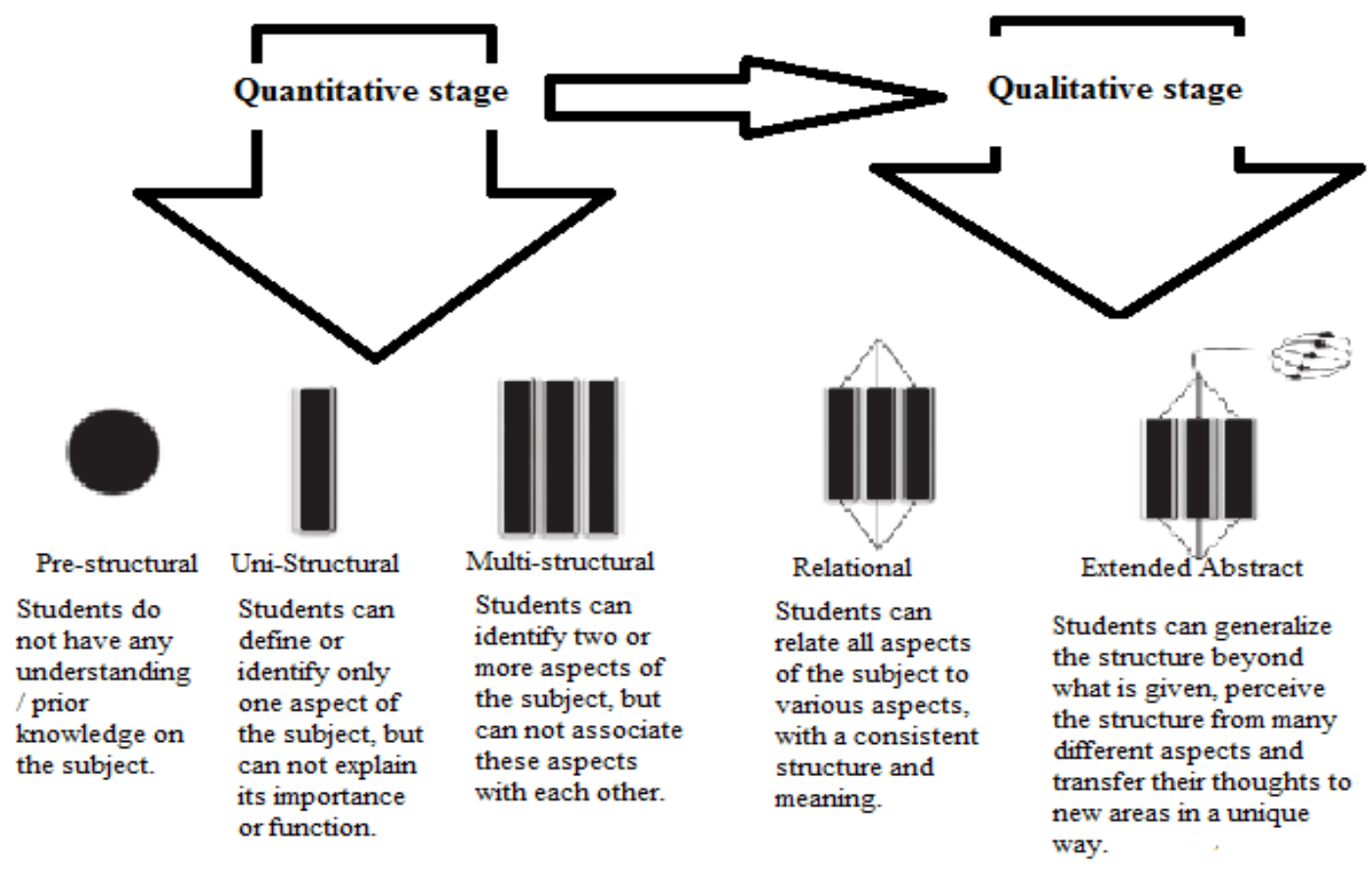

Figure 1. Stages in SOLO taxonomy 
As seen in Figure 1, SOLO taxonomy addresses cognitive complexity in a hierarchical way in five stages: Pre-structural, uni-structural, multi-structural, relational, and extended abstract. The prestructural level should be excluded, when an assessment is conducted with regard to SOLO taxonomy, as it is an unorganized, unstructured and basically invalid level considering a real content and a relationship with a topic or problem (Brabrand \&Dahl, 2009; Potter \& Kustra, 2012). SOLO taxonomy, which involves a verb list for the cognitive levels starting from the uni-structural to extended abstract level, allows the analysis of Turkish language course reading skills, designing and organizing the curriculum as well as evaluating its effectiveness, and finally evaluating the activities for the related purposes. Even though SOLO taxonomy is similar to PISA reading competency levels, there is no study about reading skill in terms of SOLO taxonomy in the literature. When the related literature was reviewed, it was found that only the 2015 curriculum, among Turkish language curriculum, was addressed in terms of SOLO taxonomy with regard to the outcomes of verbal communication skills (Göçer \& Kurt, 2016). Therefore, the purpose of this study is to find out how learning outcomes/behaviors of reading skills are distributed in the Turkish language course curriculum in terms of SOLO taxonomy cognitive levels.

\subsection{Research questions}

In alignment with the purpose of the research, the following questions were asked.

1. What is the uni-structural level of reading outcomes of the curriculums?

2. What is the multi-structural level of reading outcomes of the curriculums?

3. What is the relational level of reading outcomes of the curriculums?

4. What is the extended abstract level of reading outcomes of the curriculums?

5. What are the differences in reading outcomes of the curriculums in terms of SOLO taxonomy levels?

\section{Method}

This is a case study to reveal the cognitive levels of reading outcomes in Turkish language course curriculums. It is a qualitative research approach in which the researcher examines one or a few situations limited in time with data collection tools (observations, interviews, audio-visuals, documents, reports) that include multiple sources, and defines situations and themes depending on the situation (Creswell, 2007).

In the study, 1981, 2006 and 2019 curriculums were examined by document analysis method. Because of examining more than one unit and each unit has the sub-units, multiple case-embedded designs (Yin, 2003) were used which is one of the case study patterns.

\subsection{Data collection and analysis}

The learning outcomes that constitute the research data were taken from the secondary school Turkish language course curriculum published by the Teaching and Education Board of the Ministry of National Education in 1981, 2006 and 2019. After completing a document analysis on the reading outcomes, the data obtained were evaluated with descriptive content analysis. Cross-case synthesis which is one of the data analysis methods of the case study was used because it reveals and relates similar and different aspects by making comparisons between more than one situation (Yin, 1984). In line with this method, quantitative data obtained were divided into categories in tables and the 
categories were compared among curriculums. Descriptive analyses of quantitative data were performed and presented under the tables. Explanations of the obtained data are provided due to the nature of this exploratory case study (Yin, 2003). Each learning outcome in the curriculum was examined by taking uni-structural, multi-structural, relational, and extended abstract cognitive levels as criteria. These criteria were determined by given verb indicators in Table 4 (Biggs \& Tang, 2011, p.123; Brabrand \& Dahl, 2009, p.539):

Table 4. SOLO taxonomy cognitive levels and indicator verbs for these levels

\begin{tabular}{|c|c|c|c|}
\hline Uni-structural & Multi-structural & Relational & Extended abstract \\
\hline $\begin{array}{l}\text { Memorize, identify, } \\
\text { recognize, count, define, } \\
\text { draw, find, label, match, } \\
\text { name, quote, recall, } \\
\text { recite, follow a simple } \\
\text { procedure, tell, write, } \\
\text { imitate, calculate, } \\
\text { reproduce, arrange, } \\
\text { decide, note, seek, } \\
\text { choose, sketch, pick, } \\
\text { order. }\end{array}$ & $\begin{array}{l}\text { Classify, describe, list, } \\
\text { report, discuss, illustrate, } \\
\text { select, narrate, compute, } \\
\text { sequence, outline, } \\
\text { separate, combine, } \\
\text { account for, apply } \\
\text { method, execute, } \\
\text { formulate, use method, } \\
\text { solve, conduct, prove, } \\
\text { complete, process, } \\
\text { report, express, } \\
\text { characterize. }\end{array}$ & $\begin{array}{l}\text { Apply a given theory to } \\
\text { a related field, conclude, } \\
\text { integrate, summarize, } \\
\text { analyze, review, explain } \\
\text { the causes, argue, } \\
\text { predict, transfer, } \\
\text { substantiate, construct, } \\
\text { exemplify, design, } \\
\text { derive, adapt, structure, } \\
\text { make a plan, relate, } \\
\text { implement, compare, } \\
\text { contrast, differentiate, } \\
\text { organize, debate, make a } \\
\text { case, construct, review } \\
\text { and rewrite, examine, } \\
\text { paraphrase, translate, } \\
\text { solve a problem, } \\
\text { question, argue. }\end{array}$ & $\begin{array}{l}\text { Theorize, hypothesize, } \\
\text { generalize, create, } \\
\text { generate, compose, } \\
\text { invent, originate, make } \\
\text { an original case, prove } \\
\text { from first principles, } \\
\text { solve from first } \\
\text { principles, reason, } \\
\text { reflect, imagine, } \\
\text { evaluate, assess, } \\
\text { interpret, reflect, } \\
\text { perspectivate, criticize, } \\
\text { judge. }\end{array}$ \\
\hline
\end{tabular}

In the first stage, the learning outcomes for the reading skills in curriculums were listed by the researcher in a table. Next, two experts on education curriculum and teaching were consulted, specifically experts on learning-teaching theories and approaches in Turkish education who have studied the SOLO taxonomy. Then, each expert and I investigated the curriculum independently with reference to the SOLO taxonomy to identify the cognitive level to which each item corresponded. In the following process, the classifications of the researchers were compared in order to determine percentages of agreement between the field experts and the researcher. As a result of Miles and Huberman's (1994) formula, it was found that there were disagreements between the researchers in 5 behaviors in the 1981 program, 6 learning outcomes in the 2006 program, and 6 learning outcomes in the 2019 program. Although the level of consensus was over $70 \%$ for each curriculum (1981 curriculum - 91\%, 2006 curriculum- 88\%, 2019 curriculum - 95\%), a new session was held on the differences of opinion and a consensus was reached between the researcher and the experts.

\section{Results}

The findings of the cognitive levels of the reading outcomes in the Turkish curriculums examined were sorted and presented below. 


\subsection{Findings of reading outcomes in terms of uni-structural level}

The reading outcomes in the curriculums were examined in themes, and these themes are reading technique, reading comprehension, vocabulary, and reading habit. The distribution of each theme was calculated according to the total outcomes of each curriculum. In the 1981 curriculum, there are 42 learning outcomes except for affective and psychomotor skill outcomes (f:17). For example, the learning outcome which is to acquire the habit of following at least one daily newspaper was excluded by the reason of affective domain. 2006 curriculum consists of a total of 52 learning outcomes, 4 outcomes were excluded as they focus on the affective domain. For example, s/he organizes poetry recitation events. In the 2019 curriculum, as a result of a cyclical approach at all levels in terms of learning outcomes, there are 128 outcomes with their repetitions except for grammar learning outcomes (f:8).

Table 5. Reading outcomes in terms of uni-structural level

\begin{tabular}{|c|c|c|c|}
\hline Uni-Structural & 1981 & 2006 & 2019 \\
\hline \multirow[t]{5}{*}{$\begin{array}{l}\text { Reading } \\
\text { technique }\end{array}$} & $\begin{array}{l}\text { To be able to read meaningfully } \\
\text { (paying attention to pause, } \\
\text { emphasis, and intonation) a } \\
\text { think piece formed with } 150 \text { - } \\
300 \text { words or a story formed } \\
\text { with } 350-550 \text { words (3) }\end{array}$ & $\begin{array}{l}\text { Uses his/her voice and body } \\
\text { language effectively. }\end{array}$ & $\begin{array}{l}\text { Reads aloud and silently } \\
\text { paying attention to } \\
\text { punctuation marks (4). }\end{array}$ \\
\hline & $\begin{array}{l}\text { To be able to take notes from } \\
\text { what they read ( } 2 \text { ) }\end{array}$ & $\begin{array}{l}\text { Uses reading methods and } \\
\text { techniques. } 3\end{array}$ & Uses reading strategies 4 . \\
\hline & & Reads fluently. & $\begin{array}{l}\text { Reads texts written with } \\
\text { different fonts (4). }\end{array}$ \\
\hline & & Pronounces words correctly. & \\
\hline & & $\begin{array}{l}\text { Reads by paying attention to } \\
\text { intonation. }\end{array}$ & \\
\hline $\begin{array}{l}\text { Reading } \\
\text { comprehension }\end{array}$ & & $\begin{array}{l}\text { Learns about the author or } \\
\text { poet of a text. }\end{array}$ & \\
\hline Vocabulary & & $\begin{array}{l}\text { Uses the words, idioms, and } \\
\text { proverbs that s/he reads in a } \\
\text { text in the sentence. }\end{array}$ & $\begin{array}{l}\text { Find synonyms of words } \\
\text { (1). } \\
\text { Find antonyms of words } \\
\text { (1). }\end{array}$ \\
\hline \multirow[t]{3}{*}{ Reading habit } & $\begin{array}{l}\text { To be able to choose useful } \\
\text { books suitable for her/his level. }\end{array}$ & $\begin{array}{l}\text { Reads texts with different } \\
\text { types. }\end{array}$ & \\
\hline & $\begin{array}{l}\text { To be able to memorize poems } \\
\text { and proses s/he likes ( } 3 \text { ) }\end{array}$ & Memorizes a poem. & \\
\hline & & Memorizes short texts $\mathrm{s} / \mathrm{he}$ & \\
\hline \multicolumn{4}{|c|}{$\begin{array}{l}3 \text { Since the reading methods and techniques include audible reading, silent reading, critical reading, reading by taking notes, } \\
\text { marking, guessing, asking questions, discussing, relating to the texts, reading theater, and memorization, this acquisition is } \\
\text { shown in the uni-structural, multi-structural and relational levels. }\end{array}$} \\
\hline
\end{tabular}


likes.

To be able to make a card index Arranges a dictionary from of the text which $\mathrm{s} / \mathrm{he}$ reads. the words $\mathrm{s} / \mathrm{he}$ has learned based on what s/he reads.

\begin{tabular}{ccccccc}
\hline Total & $\mathrm{f}$ & $\%$ & $\mathrm{f}$ & $\%$ & $\mathrm{f}$ & $\%$ \\
& 10 & 23.81 & 11 & 22.45 & 11 & 8.59 \\
\hline
\end{tabular}

As seen in Table 5, the uni-structural level is mainly seen in the reading technique section. In this section, audible reading, silent reading, reading by taking notes, and paying attention to the rules of intonation and emphasis during reading stand out. Only one learning outcome in the 2006 program dealt with reading comprehension: obtaining information about a text's author. This is also valid for the vocabulary theme in 2006 and 2019 curriculums. This one learning outcome is about using a word in the sentence or finding synonyms/antonyms of the words in the texts. The reading habits theme is appeared in the 1981 and 2006 curriculums as memorizing a text, choosing a book suitable for one's own level, and arranging a dictionary of the words one learned. All of these outcomes correspond to this structure, with the indicators of memorizing, telling, writing, noting, finding, choosing, and realizing. This level was the highest in the 1981 curriculum, in terms of percentages among the curriculums (23.81\%); but in terms of frequency, the 2006 curriculum (f:11) had the highest level, if the repetition of outcomes in 2019 is excluded (f:5).

\subsection{Findings of reading outcomes in terms of multi-structural level}

The reading outcomes corresponding to the multi-structural level are found in three themes throughout the curriculums: reading technique, reading comprehension, and vocabulary. None of the learning outcomes were aimed at forming reading habits. Each outcome is shown in Table 6.

Table 6. Reading outcomes in terms of multi-structural level

\begin{tabular}{|c|c|c|c|}
\hline Multi-Structural & 1981 & 2006 & 2019 \\
\hline $\begin{array}{l}\text { Reading } \\
\text { technique }\end{array}$ & & $\begin{array}{l}\text { Uses reading methods and } \\
\text { techniques. }\end{array}$ & Uses reading strategies. \\
\hline \multirow[t]{4}{*}{$\begin{array}{l}\text { Reading } \\
\text { comprehension }\end{array}$} & & Identifies the narrator. & $\begin{array}{l}\text { Identifies the elements of } \\
\text { the story in a text (4). }\end{array}$ \\
\hline & $\begin{array}{l}\text { To be able to comprehend ideas } \\
\text { in a paragraph separately ( } 3 \text { ) }\end{array}$ & $\begin{array}{l}\text { Identifies event, setting, } \\
\text { time, characters, all living } \\
\text { things and related elements. }\end{array}$ & $\begin{array}{l}\text { Answers the questions } \\
\text { related to the information } \\
\text { presented with graphs, } \\
\text { tables, and charts (1) }\left(5^{\text {th }}\right. \\
\text { grade) }\end{array}$ \\
\hline & $\begin{array}{l}\text { To be able to comprehend the } \\
\text { news, announcements, } \\
\text { anecdotes, conversation, article, } \\
\text { interview, cartoons, etc. in } \\
\text { newspapers and magazines } \\
\text { suitable for the level (3) }\end{array}$ & & $\begin{array}{l}\text { Responds to the questions } \\
\text { about the visuals ( } 4 \text { ). }\end{array}$ \\
\hline & $\begin{array}{l}\text { To be able to comprehend } \\
\text { personal and business letters, }\end{array}$ & $\begin{array}{l}\text { Responds to the questions } \\
\text { about a text. }\end{array}$ & $\begin{array}{l}\text { Responds to the questions } \\
\text { about a text (4). }\end{array}$ \\
\hline
\end{tabular}


announcements, notices etc. (3)

To be able to comprehend a Comprehends the features of Reads the text according to scientific and technical text s/he text types. comes across in daily life (2) the characteristics of the genre (4).

To be able to outline the unique Outlines the organization of plan of an event, a think piece a text.

Comprehends the stages of or a poem (3) actions and processes in a text (2) $\quad\left(7^{\text {th }}\right.$ and $8^{\text {th }}$ Grades).

\begin{tabular}{lcccccc}
\hline Vocabulary & & \multicolumn{2}{l}{$\begin{array}{l}\text { Grasps features of form and } \\
\text { use pertaining to formulaic } \\
\text { sentence structures. }\end{array}$} & $\begin{array}{l}\text { Identifies the contribution } \\
\text { of idioms and proverbs to } \\
\text { the text (4). }\end{array}$ \\
\hline Total & $\mathrm{f}$ & $\%$ & $\mathrm{f}$ & $\%$ & $\mathrm{f}$ & $\%$ \\
& 14 & 33.33 & 7 & 14.29 & 24 & 18.75 \\
\hline
\end{tabular}

Table 6 shows that the multi-structural level is generally seen in the reading-comprehension theme. Reading-comprehension outcomes include identifying the elements (event, setting, time, characters, narrator, stages, etc.) of the text, outlining and characterizing the type of text, and answering questions. In terms of reading technique, a reading outcome of the 2006 and 2019 curriculums is discussing the reading text which is one of the reading strategies. The vocabulary theme is about phrases and using them in sentences. Among all of the curriculums compared, this level had the highest percentage in the 1981 curriculum $(33.33 \%)$. Even when the frequency of repetition in the 2019 curriculum is excluded (f:8), the 2019 curriculum had the highest frequency.

\subsection{Findings of reading outcomes in terms of relational level}

The reading outcomes corresponding to the relational level were found in four themes throughout the curriculums: reading comprehension and analysis, vocabulary, and reading habit. The learning outcomes of each category are shown in Table 7:

Table 7. Reading outcomes in terms of relational level

\begin{tabular}{|c|c|c|c|}
\hline Relational & 1981 & 2006 & 2019 \\
\hline \multirow[t]{3}{*}{ Vocabulary } & $\begin{array}{l}\text { To be able to analyze the } \\
\text { meanings of words, word } \\
\text { groups, similes, proverbs } \\
\text { and maxims in a text ( } 3 \text { ) }\end{array}$ & $\begin{array}{l}\text { Infers the meanings of } \\
\text { words and phrases through } \\
\text { the context of a text. }\end{array}$ & $\begin{array}{l}\text { Makes guesses about the } \\
\text { meaning of a word and a } \\
\text { phrase they do not know } \\
\text { by using the context (4). }\end{array}$ \\
\hline & & $\begin{array}{l}\text { Understands the meaning } \\
\text { relations between words } \\
\text { and gives examples for } \\
\text { words that are related to } \\
\text { each other in meaning. }\end{array}$ & $\begin{array}{l}\text { Distinguishes real, } \\
\text { metaphor and term } \\
\text { meaning of words in the } \\
\text { text what s/he reads }(1)\left(5^{\text {th }}\right. \\
\text { grade). }\end{array}$ \\
\hline & & $\begin{array}{l}\text { Uses words that refer to } \\
\text { the same concept area, } \\
\text { taking into account the } \\
\text { differences in meaning. }\end{array}$ & \\
\hline Reading technique & & $\begin{array}{l}\text { Uses reading methods and } \\
\text { techniques }\end{array}$ & Uses reading strategies (2). \\
\hline
\end{tabular}


Reading habit

\begin{tabular}{ll}
\hline Reading & To be able to compare and \\
comprehension and & contrast characters, events, \\
analysis & settings, and time and to be \\
Table 7. & able to find similarities and \\
(Continued) & differences (3)
\end{tabular}

To be able to comprehend the main idea, secondary thoughts and distinguish primary secondary thoughts of a speech s/he listens to or watches, a play $\mathrm{s} / \mathrm{he}$ watches and a text s/he examines (3)

To be able to differentiate stylistic properties of a poem (3)

To be able to comprehend the order of events, setting, time, causal relationship, main characters, and physical and character features of people in a movie or play $\mathrm{s} / \mathrm{he}$ watches and a text s/he reads (3)

To be able to perceive the characteristics of the authors of the texts in textbooks
Makes plans for reading

$\begin{array}{ll}\text { Identifies the keywords in } & \text { Compares the written } \\ \text { a text } & \text { version of texts (written } \\ & \text { text of the literary work) } \\ & \text { with the form as presented } \\ & \text { in media. (2) ( } 7^{\text {th }} \text { and } 8^{\text {th }} \\ & \text { Grades). }\end{array}$

Identifies the topic of a Identifies the topic of a text. $\quad$ text (4).

Identifies the main Identifies the main ideas/emotions in a text. ideas/emotions in a text (4).

Identifies the secondary Identifies the secondary thoughts/ emotions in a thoughts in a text (2) $\left(7^{\text {th }}\right.$ text. and $8^{\text {th }}$ Grade).

Distinguishes

the Distinguishes the type of differences of poetry the texts (4). language.

Explains the stylistic properties of a poem (1) (6 $6^{\text {th }}$ Grade).

Notices the cause-effect Identifies phraseologies in relationships in a text. a text $(2)\left(7^{\text {th }}\right.$ and $8^{\text {th }}$ Grades).

Notices the purpose-result relationship in a text.

Finds implicit meanings what's/he reads.

Makes inferences about what s/he reads (4).

Distinguishes subjective and objective statements when s/he reads.

Distinguishes real and fictional elements in the text (4).

Summarizes what s/he Summarizes what s/he reads in his/her own reads (4). words, in chronological order and logic flow.

Forms questions about a Asks questions about a text text. 
Makes comparisons related to a text.

Notices transitions and connections between the elements that make up a text.

Notices the contribution of the figures of speech in a text to its narration.

Explains the functions of ways to improve the thoughts in a text.

Make predictions about a text based on the clues available.

Makes fictional predictions related to events before and/or after a text.

Relates what s/he reads to his/her own life and daily life.

Reveals the relationship between the title of a text and its content.

Proposes different titles for a text s/he reads.

Makes comparisons between texts (4).

Understands how important points in the text are highlighted (4).

Identifies figures of speech in a text $\left(5^{\text {th }}\right.$ and $6^{\text {th }}$ Grade comprehension $7^{\text {th }}$ and $8^{\text {th }}$ Grades vocabulary) (4).

Identifies ways to develop ideas revealed in a text (2) ( $7^{\text {th }}$ and $8^{\text {th }}$ Grades).

Makes predictions about the topic of a text through visuals and title (4).

Uses sources of information effectively (4).

Questions the reliability of sources for information (4).

Finds title/titles appropriate to the content of the text (4).

\begin{tabular}{lcccccc}
\hline Total & $\mathrm{f}$ & $\%$ & $\mathrm{f}$ & $\%$ & $\mathrm{f}$ & $\%$ \\
& 16 & 38.10 & 25 & 51.02 & 72 & 56.25 \\
\hline
\end{tabular}

Table 7 shows that only one outcome that corresponds to the relational level in the reading habits and reading technique theme on the basis of 2006 and 2019 curriculums. The outcomes in these themes are about reading strategies and making a plan for reading. In each curriculum, the vocabulary theme is about analyzing and inferring the meaning of words and the relations between words. The reading-comprehension and analysis theme consists of comparing and analyzing the elements of the text, specifically the main idea, secondary thoughts, ways to improve the thoughts, the cause-effect and purpose-result relationships, and the contributions of the figures of speech. In addition, this theme comprises distinguishing the text type, real/fictional elements, and objective/subjective statements; summarizing the text; making predictions about the text, and asking questions about the text. Among all of the compared curriculums, this level was the highest in the 2019 curriculum, in terms of both percentages and frequency within the curriculum (56.25\%). However, the highest frequency was found in the 2006 curriculum (f:25), if the outcomes in the 2019 curriculum are calculated without repetitions (f:22 - this frequency was 72 with repetitions). 


\subsection{Findings of reading outcomes in terms of extended abstract level}

The reading outcomes corresponding to the extended abstract level were found in only one theme throughout the curriculums: reading comprehension, analysis, and evaluation. The learning outcomes are shown in Table 8:

Table 8. Reading outcomes in terms of extended abstract level

\begin{tabular}{|c|c|c|c|}
\hline Extended Abstract & 1981 & 2006 & 2019 \\
\hline \multirow[t]{6}{*}{$\begin{array}{l}\text { Reading } \\
\text { Comprehension, } \\
\text { Analysis and } \\
\text { Evaluation }\end{array}$} & $\begin{array}{l}\text { To be able to state } \\
\text { aspects and points } \\
\text { in a text that s/he } \\
\text { likes or does not } \\
\text { like with reasons }\end{array}$ & $\begin{array}{l}\text { Interprets the events, feelings, } \\
\text { thoughts and dreams by putting } \\
\text { himself/herself in the place of } \\
\text { the characters and other living } \\
\text { things in a text. }\end{array}$ & $\begin{array}{l}\text { Proposes different } \\
\text { solutions to the problems } \\
\text { addressed in a text (4). }\end{array}$ \\
\hline & (2) & $\begin{array}{l}\text { Proposes different solutions to } \\
\text { the problems revealed in a text. }\end{array}$ & $\begin{array}{l}\text { Evaluates texts in media } \\
\text { (4). }\end{array}$ \\
\hline & & $\begin{array}{l}\text { Interprets the visual elements } \\
\text { related to a text. }\end{array}$ & $\begin{array}{l}\text { Interprets related to the } \\
\text { information presented } \\
\text { with graphs, tables and } \\
\text { charts (6th, } 7 \text { th and 8th } \\
\text { Grades) (3). }\end{array}$ \\
\hline & & $\begin{array}{l}\text { Evaluates a text in terms of } \\
\text { language and expression. }\end{array}$ & $\begin{array}{l}\text { Evaluates the } \\
\text { contribution of the } \\
\text { transition and connection } \\
\text { expressions between the } \\
\text { elements that make up } \\
\text { the text to the meaning. } \\
\text { (4) }\end{array}$ \\
\hline & & $\begin{array}{l}\text { Evaluates a text in terms of its } \\
\text { content. }\end{array}$ & $\begin{array}{l}\text { Interprets the content of } \\
\text { a text (4). }\end{array}$ \\
\hline & & $\begin{array}{l}\text { Expresses the emotions that a } \\
\text { poem evokes. }\end{array}$ & \\
\hline \multirow[t]{2}{*}{ Total } & $\%$ & $\%$ & $\%$ \\
\hline & 4.76 & 12.24 & 16.41 \\
\hline
\end{tabular}

Table 8 shows only one reading outcome in the 1981 curriculum at this level. The reading outcomes in the 2006 and 2019 curriculums had similar frequencies. The 2006 curriculum had six outcomes, and the 2019 curriculum had five outcomes, excluding the repeated outcomes. The outcomes in this theme generally focused on interpreting, evaluating, assessing, and finding solutions according to the principles of the text. The 2019 curriculum had the highest percentage of the outcomes $(16.41 \%)$.

\subsection{Findings of the differences in reading outcomes in the curriculums}

The differences in the reading outcomes in terms of cognitive skills and subskills of reading are shown in Figure 2: 


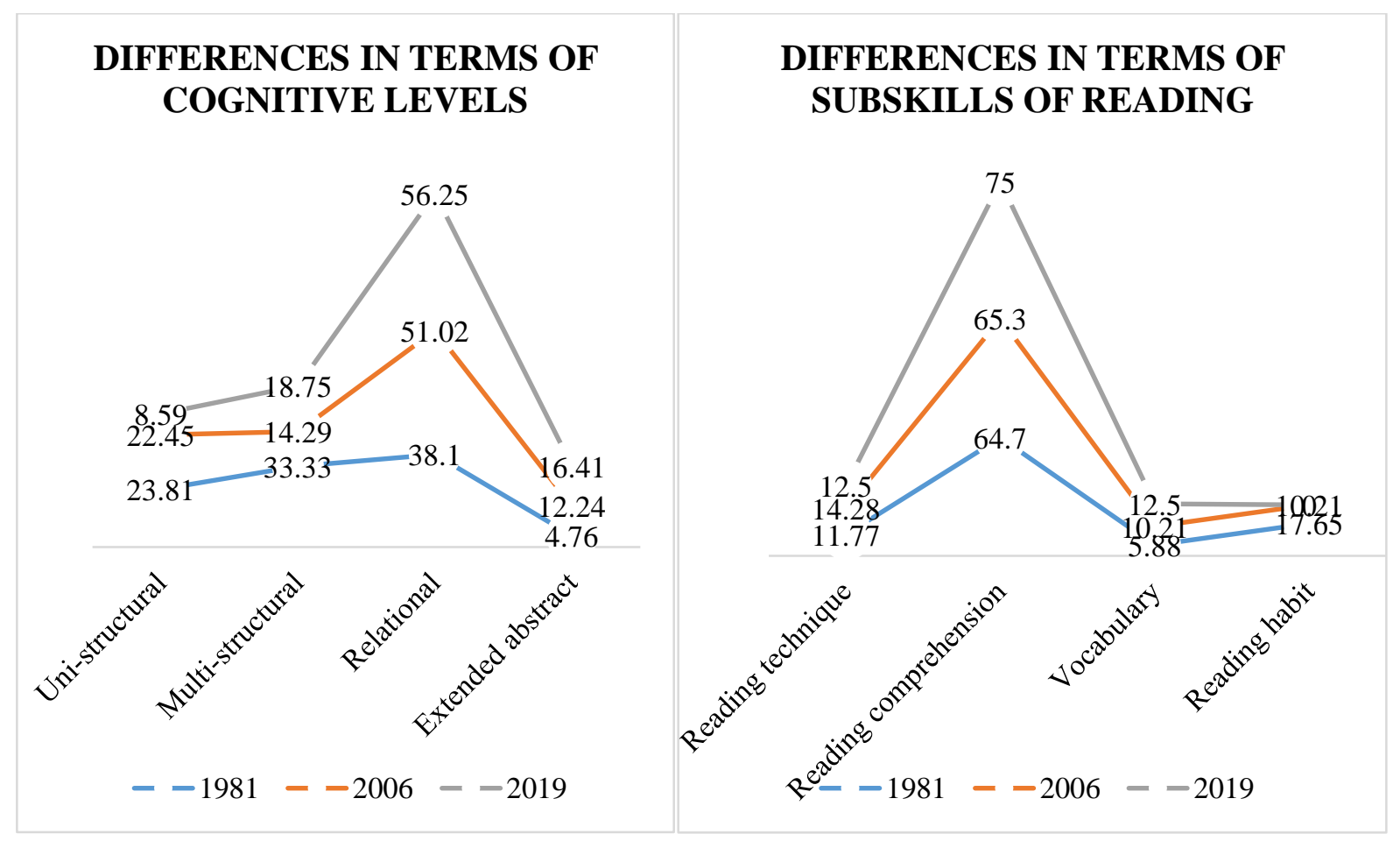

Figure 2. Differences among reading outcomes in curriculums

As shown in Figure 2, the relational level stands out in terms of percentage, which was highest in the 2019 curriculum. This level is followed by the multi-structural, extended abstract, and unistructural levels in the same curriculum, respectively. While the uni-structural level has been decreasing over the years, the relational and extended abstract levels have increased. However, even though the extended abstract level has increased over the years, it is still one of the lowest levels in the curriculums. The multi-structural level was most prevalent in the 1981 curriculum, but it did not show a gradual increase over the years.

The most widely used reading subskill was the reading comprehension theme. This means that reading comprehension outcomes generally correspond to the relational level. These rates can be ordered as reading technique, reading technique, and habits. Because reading habits are also an affective skill, the reading outcomes at this theme mostly correspond to the uni-structural level. Reading technique is defined as audible reading, silent reading, and reading by taking notes in the 1981 curriculum at the uni structural level. However, the 2006 and 2019 curriculums comprise various methods and strategies. Thus, the reading outcomes in both curriculums are seen at the uni structural, multi-structural, and relational levels.

\section{Discussion}

In this study, three curriculums for reading skills were analyzed in terms of the SOLO taxonomy. The SOLO framework helps designers to discover instances in which instruction components (curriculum, activities, assessment tools, etc.) might need to be revised (Rembach \& Dison, 2016). Such an analysis of curriculum allows the identification of skills that students are lacking; therefore, it enables to identify the skills that should be included in the curriculum in a coordinated way (Langer, 1984). In the 1981 curriculum, in line with behaviorism, a series of goals and behaviors were planned for the students to acquire, and the curriculum mostly included the relational level, at $38.1 \%$, followed by the multi-structural level at $33.33 \%$. While the uni-structural level is included at the rate of $23.81 \%$, 
the extended abstract level is the least with the proportion of $4.76 \%$. It is possible to state that this curriculum was aimed at having students acquire the skills of ordering concepts according to various features and of noticing the relationships between these concepts. The 2003 and 2006 PISA reading exam results show that students at the second level are more successful and that the rates over the years are similar. Level 2 requires the skill of "comparing non-textual information to the text content, establishing relationships or explaining a feature of a text-based on personal experience and attitudes" (MoNE, 2005, p. 116). In this respect, the PISA reading results support the results obtained in the present study.

The 2006 curriculum is aimed at employing higher-order thinking skills as a result of the constructivist approach on which it is based. However, the rate at which learning outcomes are included at the uni-structural level $(22.45 \%)$ was similar to that of the 1981 curriculum $(23.41 \%)$. According to Batur and Alevli (2014), the curriculum should be reviewed in more detail to serve the higher-order reading skills in PISA. In terms of the SOLO taxonomy, the extended abstract level - the highest cognitive level in the taxonomy-was included the least in the curriculum, at $12.24 \%$. Batur and Ulutaş (2013) reported that 18 of the 51 learning outcomes corresponded to lower-level reading comprehension skills in PISA. The answers are given by the students to the PISA exam questions also support this situation: "A majority of the Turkish students who were at or below the second level of reading scale obtained a relatively lower average of correct answers for short-response and openconstructed-response questions, which require a higher level of cognitive processing" (Bozkurt, 2016, p. XX). This is similar to the results of the present study. Moreover, the extended abstract level was the least included level in the 2006 curriculum. This is also valid for the curriculums for other subjects (Gezer \& İlhan, 2014; Göçer \& Kurt, 2016; Korkmaz \& Ünsal, 2017).

The learning outcomes at the relational levels were more prominent in the 2006 curriculum (51.02\%). Other studies conducted had similar results regarding the domination of the relational level (Göçer \& Kurt, 2016; Korkmaz \& Ünsal, 2010). However, the most successful students in 2009, 2012 , and 2015 PISA exams were those at the second level. Although progress was made at the fourth, fifth, and sixth levels in 2012, the ratio in 2015 was lower than that of even the 2006 results. In addition, the highest score at the fourth level was achieved in the 2012 exam. According to the PISA reading competencies, the students at the fourth level have the skill of "editing a text by deciding on the information required for the text and considering the text as a whole and interpreting language differences" (MoNE, 2015, p. 98). This is an indication of the relational level in the SOLO taxonomy; although this structure was most prominent in the 2006 curriculum, it was reflected only in the 2012 curriculum.

Similar to the 2006 curriculum, the learning outcomes at the relational level constitute more than half of the 2019 outcomes (56.25\%). Moreover, the extended abstract level was the highest in this curriculum. According to Applebee's (1978) systematic model, students at Formal Operational Stage 1 can analyze the structure of a work and also the characters' motives through analogy. For this analysis, children must be aware of the forms, conventions, devices, and techniques of literature (Britton, 1968). This is why learning outcomes at an extended abstract level are required for improving students' thinking skills. The general distribution of the reading outcomes in curriculums is insufficient for students to acquire abstraction skills, even though the 2019 curriculum stands out among the curriculums. Karadag and Tekercioglu (2019) found similar consequences in text-based activities in terms of metacognitive functions. And also, in Ozdemir's (2021) study, the learning outcomes in the Turkish course curriculum were found to have moderate or lower adequacy in terms of including critical thinking skills.

The relational level stands out for its dominance in each curriculum. All of the curriculums can be characterized by transitivity in terms of cognitive operations; however, proportionality and correlation 
did not seem to be included (Decano, 2017). In addition, the transitions among class levels did not show gradual advancement gradually regarding cognitive operations, as also stated by Gezer and İlhan (2015). PISA reading exam results also support this aspect of the curriculum. At Level 4, there was a gradual improvement between 2003 and 2012 reading exam scores. While the rate of the relational level was $38.1 \%$, this level increased in the 2006 curriculum, at a rate exceeding $50 \%$. However, the reading exam scores did not differ at Level 5 in terms of progression, and the scores at Level 6 were not at the expected rate. Therefore, because the students' levels increased from the fifth grade to the eighth grade, the outcomes corresponding to the sixth level should be increased.

When the three curriculums are compared in terms of the reading subskills, reading comprehension stood out in each curriculum. The least-often included level in the curriculums was reading habits. Because this theme reflects both cognitive and affective skills, only the outcomes of this theme were examined in terms of thinking skills. In the examination, this theme stood out at the uni structural level. Hanedar (2011) found that the reading skills of eighth-grade students were lower than the expected level for the reading curriculum outcomes and that not enough reading habit activities are included in textbooks. Additionally, students who have high reading habits have better reading comprehension than those who have low reading habits (Rosyida \& Ghufron, 2018). According to Palani (2012), reading habits help students to develop the proper thinking methods and create new ideas. Hence, the outcomes of reading habits may be insufficient to develop higher thinking skills.

The reading technique and vocabulary themes were the least included in the 1981 curriculum. While reading technique themes stood out more than vocabulary did in the 2006 curriculum, these two themes had equal rates in the 2019 curriculum. According to Kurnaz (2018), reading strategies contributed to the success levels of reading comprehension in expository texts indirectly through vocabulary knowledge. Therefore, vocabulary knowledge and reading strategies must be handled in a coordinated manner with the curricular reading outcomes for the reading-comprehension skill. The 2019 curriculum stands out on this point. To make up for this deficiency in curriculums, it is useful to find answers to the following question according to the SOLO framework: What stage-specific cognitive operations must preadolescents do when reading a text? (Galda, 1980, as cited in Fusco, 1983). In answering this question, future curriculums require four commonalities to develop learning experiences and to learn how to learn: a common learning language (SOLO's coded visual-mapping and self-assessment rubrics), common learning interventions (SOLO's coded-thinking skills and strategies, and information communication technologies), common understanding of the learning process (the SOLO competencies), and common classroom practices (SOLO's coded learning intentions, learning experiences, and assessment for learning) (Hook, 2012). To prepare a reading curriculum based on these commonalities, it is important to define the deficiencies of the curriculums.

\section{Conclusions}

In this study, the reading outcomes were examined to determine the level of cognitive skills in mother-tongue curriculums in Turkey through the relationship between the SOLO taxonomy and PISA reading proficiencies. PISA reading proficiencies at Levels $1 \mathrm{a}$ and $1 \mathrm{~b}$ corresponded to the uni structural level, and Level 2 corresponded to the multi-structural level. Levels 3 and 4 corresponded to the relational level, and Levels 5 and 6 corresponded to the extended abstract level. Because the extended abstract level stood out least among the reading outcomes, the reading curriculums must be revised. For this level, each outcome should be taken into account according to three reading literacy categories defined by PISA. In this framework, the outcomes in Figure 3 must be included in reading curriculums. Thus, each curriculum should consider reading outcomes for both cognitive levels and reading subskills in a balanced way. It can be said that such a revision will improve student literacy levels. 


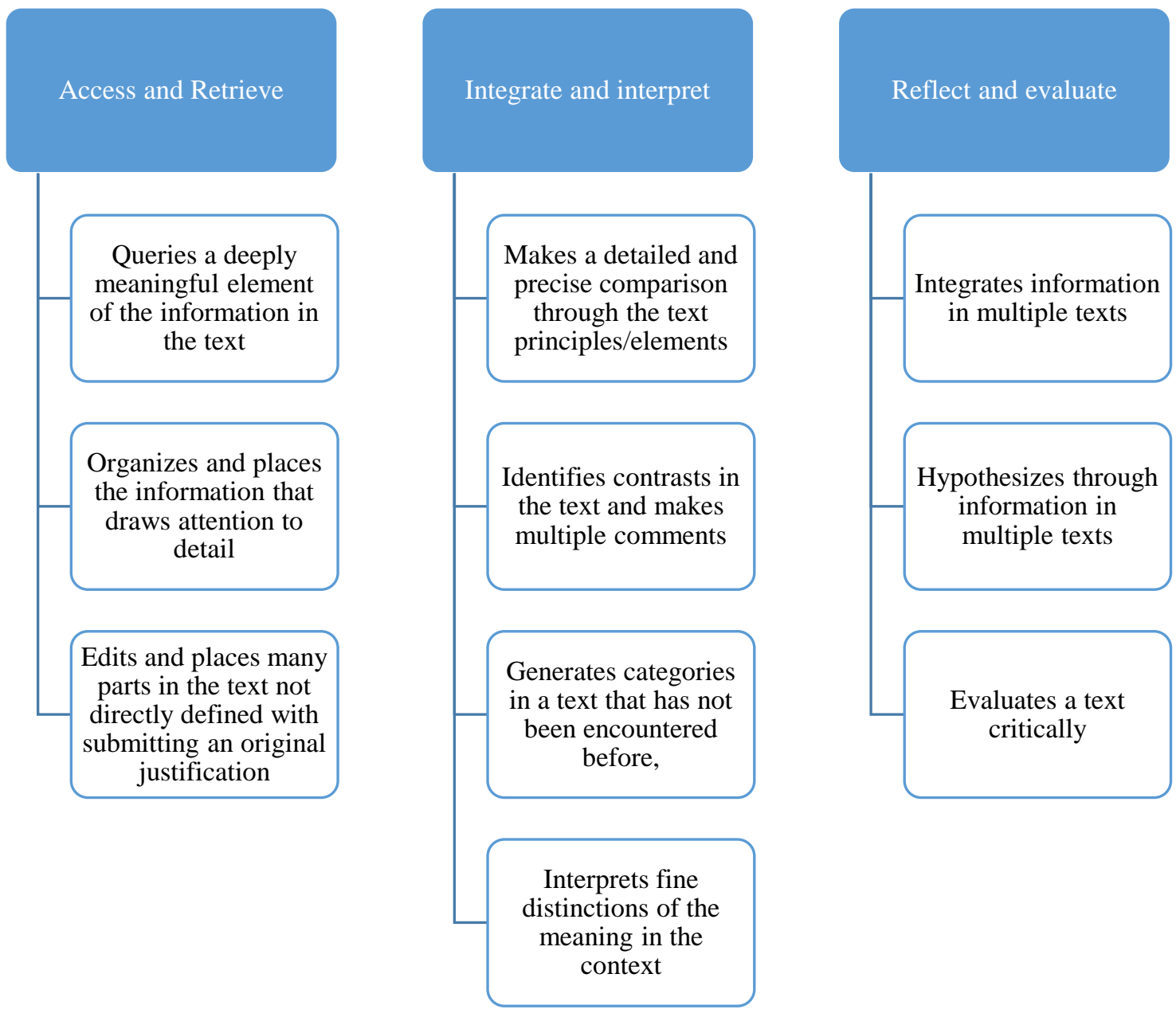

Figure 3. Reading outcomes for extended abstract level

There is a need to determine outcomes for the extended abstract level; as seen in Figure 3, the outcomes were determined according to the PISA reading categories. Thus, this deficiency should be remedied by using the SOLO taxonomy indicator verbs for the extended abstract level. In addition, these indicators should be reflected in curriculums, textbooks, assessments, and evaluation tools.

\section{Ethics Committee Approval}

The author confirms that the study does not need ethics committee approval according to the research integrity rules in her country.

\section{References}

Applebee, A.N. (1978). The child's concept of story: ages two to seventeen. Chicago: Chicago University Press.

Ar1, A. (2013). Revised Bloom, SOLO, Fink, Dettmer taxonomies in cognitive area classification and their international recognition cases. Uşak Üniversitesi Sosyal Bilimler Dergisi, 6(2), 259-290.

Batur, Z, \& Alevli, O. (2014). An examination of reading skills course in terms of PISA reading comprehension competencies. Research in Reading \& Writing Instruction, 2(1), 22-30. 
Batur, Z. \& Ulutas, M. (2013). An analyze of the correspondence levels between Turkish reading proficiency objectives and the PISA scale. International Journal of Social Science, 6(2), 15491563.

Biggs, J.B. \& Collis, K.F. (1982). Evaluating the quality of learning- the SOLO taxonomy (structure of the observed learning outcome). New York: Academic Press.

Biggs, J. \& Tang, C. (2007). Teaching for quality learning at university. Maidenhead: Open University Press.

Bozkurt, B. Ü. (2016). A report on reading instruction in Turkey: implications from PISA scale. Abant İzzet Baysal Üniversitesi Eğitim Fakültesi Dergisi, 16 (4), 1673-1686.

Brabrand, C. \& Dahl, B. (2009). Using the SOLO taxonomy to analyze competence progression of university science curricula. High Education, 58, 531-549. DOI: 10.1007/s10734-009-9210-4

Britton, J. (1968). Response to literature. In J.R. Squire (ed.), The Dartmouth seminar papers: response to literature (pp. 3-10). Champaign, Illinois: National Council of Teachers of English.

Burnett, P. C. (1999). Assessing the structure of learning outcomes from counseling using the SOLO taxonomy: an exploratory study. British Journal of Guidance \& Counselling, 27(4), 567-580. DOI: $10.1080 / 03069889908256291$

Cin Şeker, Z. (2020). Attitudes of Turkish teacher candidates towards discussion. Journal of Language and Linguistic Studies, 16(2), 993-1005. Doi: 10.17263/jlls.759355

Creswell, J. W. (2007). Qualitative inquiry \& research design: Choosing among five approaches (2th Ed.). USA: SAGE Publications.

Decano, R.S. (2017). Cognitive development of college students and their achievement in geometry: an evaluation using Piaget's theory and Van Hiele's levels of thinking. ISTEL-Winter Bangkok, Thailand- 24-26 January 2017, 3(1), pp.55-79. Taipei: International Business Academics Consortium.

Fusco, E.T. (1983). The relationship between children's cognitive level of development and their responses to literature (schema, reasoning, taxonomy). Unpublished doctoral dissertation. Hofstra University, New York.

Gezer, M. \& İlhan, M. (2014). An evaluation of the assessment questions in the textbook and objectives of the 8th-grade curriculum citizenship and democracy education course according to SOLO taxonomy. Dogu Cografya Dergisi, 19(32), 193-208.

Gezer, M. \& İlhan, M. (2015). An analyzing of the assessment questions in the textbook and objectives of the curriculum social studies course according to the SOLO taxonomy. Sakarya Üniversitesi Eğitim Fakültesi Dergisi, 29, 1-25.

Göçer, A. \& Kurt, A. (2016). Turkish course education programme, 6, 7, and 8th class verbal communication gains examining according to the SOLO taxonomy. Journal of Bitlis Eren University Institute of Social Sciences, 5 (December), 215-228.

Hanedar, R.F. (2011). Book reading habits of students in 8th grade and research on the reading comprehension skills. Unpublished master's thesis. Dokuz Eylul University, Education Sciences Institute, Izmir.

Hattie, J.A.C. \& Brown, G.T.L. (2004, September). Cognitive processes in asTTle: The SOLO taxonomy. asTTle Technical Report 43. University of Auckland/ Ministry of Education. 
Hook, P. (2012). Teaching and learning: tales from the ampersand. In L.Rowan \& C. Bigum (Eds.). Transformative approaches to new technologies and student diversity in futures-oriented classrooms (pp.115-138). Dordrecht: Springer.

İlhan, M. \& Gezer, M. (2017). Comparison of the reliability of the SOLO- and revised Bloom's taxonomy-based classifications in the analysis of the cognitive levels of assessment questions. Pegem Eğitim ve Öğretim Dergisi, 7(4), 637-662. DOI: 10.14527/pegegog.2017.023

Karadag, Ö., \& Tekercioglu, H. (2019). A Case Study on Cognitive and Metacognitive Functions in Turkish Textbooks. Mersin University Journal of the Faculty of Education, 15(3), 628-646. DOI: 10.17860/mersinefd.594240

Korkmaz, F., \& Ünsal, S. (2017). Analysis of attainments and evaluation questions in sociology curriculum according to the SOLO taxonomy. Eurasian Journal of Educational Research, 69 (2017), 75-92. DOI: 10.14689/ejer.2017.69.5

Kurnaz, H. (2018). Factors that affect reading comprehension in expository texts. Unpublished doctoral dissertation. Inonu University, Education Sciences Institute, Malatya.

Langer, J. A. (1984). Literacy instruction in American schools: Problems and perspectives. American Journal of Education, 93(1), 107-132. DOI: 10.1086/443788

Li, J., Gao, L., \& Cao, Q. (2011). A comparative study of the levels of SOLO and the levels of appraisal grades of PISA. Curriculum, Teaching Material and Method, 31(4), 91-96.

Meagher-Lundberg, P., \& Brown, G. T. L. (2001). Item signature study: Report on the characteristics of reading texts and items from calibration 1. (Technical Report No. 12). Auckland, NZ: University of Auckland, Project asTTle.

MoNE (1981). Turkish language curriculum for primary education. Ankara: Republic of Turkey Ministry of Education.

MoNE (2005). PISA 2003 project national final report. Ankara: Republic of Turkey Ministry of Education. Retrieved on May 6, 2020, from http://pisa.meb.gov.tr/wpcontent/uploads/2013/07/PISA-2003-Ulusal-Nihai-Rapor.pdf

MoNE (2006). Turkish language curriculum for primary education (6-8th grades). Ankara: Republic of Turkey Ministry of Education.

MoNE (2010a). PISA 2006 project national final report. Ankara: Ankara: Republic of Turkey Ministry of Education. Retrieved on May 6, 2020, from http://pisa.meb.gov.tr/wpcontent/uploads/2013/07/PISA2006-Ulusal-Nihai-Rapor.pdf

MoNE (2010b). PISA 2009 national preliminary report. Ankara: Ankara: Republic of Turkey Ministry of Education. Retrieved on May 6, 2020, from http://pisa.meb.gov.tr/wpcontent/uploads/2013/07/PISA-2009-Ulusal-On-Rapor.pdf

MoNE (2015). PISA 2012 survey national final report. Ankara: Republic of Turkey Ministry of Education. Retrieved on May 5, 2020, from https://drive.google.com/file/d/0B2wxMX5xMcnhaGtnV2x6YWsyY2c/view

MoNE (2016). PISA 2015 national report. Ankara: Ankara: Republic of Turkey Ministry of Education. Retrieved on May 5, 2020, from http://odsgm.meb.gov.tr/test/analizler/docs/PISA/PISA2015_Ulusal_Rapor.pdf

MoNE (2019). Turkish language curriculum (elementary and middle school 1-8th grades. Ankara: Republic of Turkey Ministry of Education. 
MoNE (2019). PISA 2018 national preliminary report. Ankara: Republic of Turkey Ministry of $\begin{array}{lllll}\text { Education. Retrieved } \quad \text { on } & \text { May 2020, from }\end{array}$ http://www.meb.gov.tr/meb_iys_dosyalar/2019_12/03105347_PISA_2018_Turkiye_On_Raporu.p df

Ozdemir, B. (2021). Investigation of the objectives in the Turkish course curriculum in terms of including critical thinking skills. Journal of Language and Linguistic Studies, 17(Special Issue 2), 735-751.

Palani, K.K. (2012). Promoting reading habits and creating a literate society. Journal of Arts, Science \& Commerce, 2(1), 90-94.

Potter, M., \& Kustra, E. (2012). A primer on learning outcomes and the SOLO taxonomy. Centre for Teaching and Learning, University of Windsor. Retrieved on October 26, 2020 from http://www.uwindsor.ca/ctl/sites/uwindsor.ca.ctl/files/primer-on-learningoutcomes .pdf

Rembach \& Dison (2016). Transforming taxonomies into rubrics: Using SOLO in Social Science Perspectives in Education. Perspectives in Education, 34(1), 68-83. DOI: http://dx.doi. org/10.18820/2519593X/pie. v34i1.6

Rosyida, F., \& Ghufron, M.A. (2018). Herringbone and tri focus Steve Snyder technique: The techniques for teaching reading comprehension viewed from students' reading habit. International Journal of Instruction, 11(3), 603-616.

Senemoğlu, N. (2012). Gelişim, ögrrenme ve ögretim- kuramdan uygulamaya [Development, learning and teaching - from theory to practice]. Ankara: Pegem Akademi.

Strike, K. A. \& Posner, G. J. (1985). A conceptual change view of learning and understanding. In L. H. T. West \& A. L. Pines (Eds.), Cognitive structure and conceptual change (pp. 211-231). Academic Press: New York.

Yin, R.K. (2003). Case study research: design and methods. (3th Ed.). California: Sage Publications.

\section{AUTHOR BIODATA}

Sevil Hasirci Aksoy since receiving the title of doctor in the field of Turkish Education in 2015, she has been working on children's literature, reading education, speaking education, and teaching Turkish to foreigners. She teaches undergraduate and graduate courses in these areas. She is currently working as Assistant Prof. in Gaziantep University, Department of Turkish and Social Sciences Education. 